\title{
From Refugees to Forced Migration: The UNHCR and Human Security ${ }^{I}$
}

Howard Adelman

York University

Within UNHCR, there has been a shift in the emphasis on the meaning of protection. Protection of refugees is now primarily defined as security of refugees and refugee operations rather than in terms of the legal asylum process. The article examines the significance of UNHCR placing the refugee issue within both the larger context of forced migration as well as within the context of human security. The paper clarifies and documents a current and general focus of forced migration that includes the internally displaced as well as refugees and offers a framework for comprehending and dealing with the refugee problem that has shifted focus to the security dimension.

In the document UNHCR Strategy towards 2000 (Geneva, 1997), the primary challenge facing the UNHCR was said to be the fact that "[P]opulation displacements are more than ever perceived as a threat to economic, social and environmental stability, as well as political security." Was this additional evidence that the UNHCR was abandoning the concern for the protection of refugees for an emphasis on forced migration in general and in relationship to the political security of states and economic/social stability? Per the UNHCR's own account, it was only trying to adapt itself and its mandate to changing circumstances to understand the problem of refugees as one aspect of human displacement within the context of the issue of security - security of refugees and humanitarian workers as well as states. The UNHCR was not abandoning its concern with "the security of refugees and refugee operations" (Ogata, 1999).

However, protection of refugees was now being defined as security of refugees and refugee operations rather than in terms of the legal asylum process. While seven years earlier, Ogata had stressed the importance of security while maintaining "the continued importance of asylum," (Ogata, 1992) somehow asylum seemed to have shifted further towards the periphery of UNHCR's vision (see, e.g., Goodwin-Gill, 1999; Chimni, 1998; Roberts, 1998). The new emphasis positioned the UNHCR concern with refugee protection within a security paradigm. What is the meaning of UNHCR placing

II am grateful for the comments of the participants that were so helpful in preparing this revised draft. 
the refugee issue within both the larger context of forced migration as well as within the context of human security? What is its significance?

This article clarifies and documents a current and general focus on forced migration that includes the internally displaced as well as refugees. Further, the framework for comprehending and dealing with the problem has shifted to the security dimension - political, social, economic and even environmental instability - that human beings pose when forced to flee their homes. The security focus matches a historical shift because human security is an issue stressed by scholars and state policymakers, as well as the UNHCR. Further, it does not matter whether those people are internally displaced or cross an international border. What does matter is that, in the current emphasis, the forced migration of peoples is seen as adding to an environment of insecurity just as much as the masses who are forced to move are both products and victims of insecurity.

After documenting that this is the case and the factors and characteristics associated with this new emphasis, that is, that refugees and the internally displaced are now viewed very broadly through a security lens, I ask a counterfactual question. How else could refugees be viewed and what would the implications be for the UNHCR? I ask the question about possible worlds. If the security lens is the actual one through which we and the UNHCR currently view those forcefully displaced from their homes, what are some other possible ways that we could have viewed those who are forced to move?

I ask this question about possibilities not because I want to be nostalgic about what could have been. Nor is it the case that I fancy myself as a writer of science fiction. Most of all, I am not engaging in this exercise because I want to serve as a superego - holding up these alternatives as ways of browbeating and embarrassing the UNHCR - as well as most of the rest of us for our moral failures. I am not raising these orher possibilities to assert that if the UNHCR, or if I for that matter, had been made of stronger moral fiber, if we had been constituted with greater moral strength and determination, then the UNHCR would not have drifted into this wayward path. I will, on the way, point to those who berate the UNHCR for its current emphasis and for its failure in not doing something else. But that is not my purpose. I am not here to offer a moral compass to the UNHCR.

Rather, I want to add what I believe is a significant and neglected dimension to explain why the UNHCR is what it is. And I want to do so not by accounting for what the UNHCR is in terms of current constraints, forces and circumstances, though these are undoubtedly important factors. Nor do 
I intend to trace the trajectory of the development of the UNHCR, though such a story is critical to understanding the changes that have taken place in the UNHCR and explaining the choices UNHCR made to change direction along the way. I intend to ignore that development entirely even though I consider the course of development critical to explaining why the UNHCR is what it is today. Rather, I will engage in hypothetical testing.

\section{HYPOTHESIS}

To understand that test, it is important that I declare what I intend to do. After I have documented the inclusion of the internally displaced within the concern of the UNHCR and have elaborated the security lens for understanding that forced migration, I will then explore a few possible alternative worlds. I then will set forth a thesis about the origins of the UNHCR that conditioned (not determined) the UNHCR to operate within a certain range of possibilities and not in other ways. Let me call this "the conditioning thesis." This thesis asserts that in the genesis (as distinct from kinesis, the process of change and transformation in an organization) a template is laid down which limits the choices for an organization. It sets parameters which make it possible for an organization to make some choices and very difficult to make others. Such an account doesnot explain the choices made along the way, but only the boundaries within which those choices are made.

The conditioning thesis differs from three orher predominant accounts of the development of the UNHCR, but is not inconsistent with any of them exept when they are taken as absolute and exclusive explanatory accounts. One is the continuity thesis. It argues that although the UNHCR is subjected to external pressures and constraints, as an autonomous actor, the UNHCR seeks to respond and adapt to changing conditions in order to both survive and to protect its mandate as best it can. This is the thesis of the UNHCR itself. It is also the thesis of several of the critical accounts of the UNHCR.

The conditioning thesis and the continuity thesis both differ from the conservative thesis of fundamentalist scholars such as Guy Goodwin-Gill, who argue that the essential mandate of the UNHCR is legal protection which is primarily identified with asylum. The shift to the repatriation paradigm in the nineties, and subsequently to the human security paradigm, in the development of UNHCR as the organization became the preeminent active humanitarian aid agency was perceived by the conservatives as a fundamental subversion of UNHCR's essential mandate. This is not just an abstract debate. UNHCR, in a pragmatic mode, claimed that it understood 
the Macedonian fear that the Kosovo refugees would have a destabilizing effect on the fragile demographic balance within Macedonia. The UNHCR took the security concerns of Macedonia into account and accepted the principle of burden sharing as a precondition before Macedonia would continue to permit the entry of Kosovar refugees. When the UNHCR adopted this tactic, the fundamentalist essentialist conservative critics of the UNHCR accused the organization of surrendering its principles and succumbing to host government blackmail. The conservative thesis is a moral rather than an explanatory thesis. It does not attempt to explain change as much as document a role said to be essential and unique to the UNHCR and to evaluate the activities of UNHCR in terms of that claimed essential function.

There is a fourth position that contrasts with the continuity, conservative and my own conditioning theses. Critical theorists, like political realists, argue that the UNHCR is simply a pawn of state and, hence, capitalist interests. As such, UNHCR is a conflicted organization torn between its legal and human rights obligations and its cow-towing to the Western states that pay its bills. The critical theorists agree with the realists that the UNHCR is not an independent actor but is subject to the interests of the powerful states that it serves. Only the critical theorists regard this as a matter of negative judgement rather than descriptive fact. The UNHCR is a minion of the wealthy Western states and totally externally determined in its actions. This contrasts with the continuity theorists who claim that the UNHCR is an autonomous actor that responds pragmatically to changing conditions within the pressures and constraints under which it operates. Both my own conditioning thesis and the continuity thesis are explanatory rather than evaluative frames for understanding the UNHCR rather than judging it, though such explanations allow room for judgment as to why alternative options were not taken. Though the critical theory perspective claims to be explanatory as well as evaluative, the conservative assessment is primarily evaluative. The conservatives (they are primarily legal scholars) judge the UNHCR morally, arguing that the UNHCR has acted as an imperialistic opportunist and/or as a coward by betraying its fundamental values in pursuit of institutional hegemony in the international humanitarian field.

Whether the UNHCR is influenced by external factors or by internal thought processes, desires and/or fears, I argue that it is also programmed by its genetic origins (by 'genetic' I do not mean that the UNHCR has something equivalent to genes; I refer to genesis, the coming into being of the agency). Those origins have given the UNHCR a disposition to respond in certain ways. 
This does not mean that it could not change or that it did not change. Quite the contrary. The UNHCR did change in response to external conditions and constraints and pressures. I suggest that the repertoire of possible responses was programmed into the UNHCR from the beginning. Thus, I will describe in some detail the job that the UNHCR inherited when it was founded.

It is often claimed that it was the Cold War that set the UNHCR on its path. I argue that the imprinting of the UNHCR came earlier. Though UNHCR's initial task may have focused on those who feared persecution from communist regimes, this was not necessarily the origin of the template that set forth the realm of possibilities and the parameters for UNHCR. It is certainly correct that this is how the United States viewed the UNHCR and refugees in the beginning (see, e.g., Loescher and Scanlan, 1986). I argue that the policies of the UNHCR were not simply by-products of the Cold War. The framework for the UNHCR's mandate was set prior to the onset of the Cold War. Institutions, like individuals, are very deeply imprinted in their formative years. These factors do not determine what the organization or individual will become, but they set very strong parameters. Thus, I will emphasize the critical importance of the precursors to the UNHCR that provided the primary template for the UNHCR.

Though these early foundations do not determine who we are and who we can be, they set very severe limits. The genesis of an institution predisposes that institution to react to circumstances and challenges in characteristic ways. If an organization, or an individual, is not to be restricted and unduly bound by such parameters, it is crucial that they be brought into the open. As the institution adapts to a changing world, as that institution rediscovers and recreates itself anew in response to those challenges, or is forced and pressured to make such changes, it will only be possible to go beyond the very restrictive boundaries set by those codes and conditions to the degree that the organization understands its own genesis and emotional imprint. I stress the term 'possibility' because I am unsure whether an organization can make such a leap.

This effort is not a case of retrospective psychoanalysis of the UNHCR. Rather, we as individuals and all institutions have "gut" reactions. Very early, we are programmed to respond to certain objects and events with repeatable responses. As the neuro-scientists put it, our visual inputs travel down our cognitive low road, activating the amygdala and stimulating either a strong negative or positive reaction without being processed through our conscious brain (Le Doux, 1999). Very early on, we are programmed deeply to respond emotionally and strongly to certain cues. 
I do not intend to trace the cues that the UNHCR responded to which help explain the shifts in its course. However, the beginning of the Cold War and the identification of the Soviet Union as an empire that persecuted its citizens was certainly such a cue. But it was not the source of the template itself. I argue that the source was rooted in the persecution of the Jews by the Nazis. It was flight from Nazi rather than communist persecution that provided the basic template for the UNHCR. Further, in the political debates at the time, the predominant view was that these Jews had to be resettled and not repatriated. The debate over repatriation versus resettlement set the template for the International Refugee Organisation (IRO) and provided the template for the UNHCR.

This article is not only intended to provide a missing element to help explain the character and development of the UNHCR. It is hypothetical because the paper does not document the history to demonstrate just who influenced and how they influenced the parameters given to the UNHCR. This is not a detailed explanation of the genesis of the UNHCR in terms of original intentions, conditions, goals and anticipations of those who set out to create the UNHCR. That would be a much larger task and far beyond the scope of this paper.

Further, this is not an exclusivist explanatory argument. The conservative, continuity and critical theoretical approaches to explaining UNHCR history are not necessarily incompatible except when turned into absolutist doctrines. It is possible to be a moral traitor to a cause and still have a template. It is possible to be an organization that makes choices in response to changing circumstances and still have parameters that limit those choices. It is possible to be strongly (but not totally) influenced by external actors and still have a fundamentally internalized program established in the genesis of the organization. I want to explore the conditioning thesis as a basic contributor to the character that the UNHCR has today.

What was the job of the UNHCR when it was founded? Why was it given that task? How did the "hits" - genetic, psychological, social - that unconsciously framed the UNHCR limit the possibilities for the UNHCR? These are the questions I focus upon once I depict in greater detail the security focus of the UNHCR today and the inclusion of the internally displaced within its mandate. These are the questions that I have in mind when I engage in an exercise of the imagination in depicting other logical, though not likely actual, possibilities. I say focus because there is no effort to provide a definitive historical answer here. Rather, I do so to suggest the importance of this added explanatory factor, to suggest what it might be, and to argue that the current stress on human security and the inclusion of the internally displaced is, in fact, thor- 
oughly consistent with that original template and one expression of its possibilities.

Finally, the aim of this paper is not to berate UNHCR for shifting from its "true" mandate (see, e.g., Roberts, 1998), but to understand the roots of the possibilities in the shifts that actually took place. The intention is to place the issue of refugees within the framework of conditions put in place in the first half of this century. This historical framework moves from the present emphasis in contrast to other possibilities to the origins of the UNHCR as one key reason for explaining why those other alternatives were not pursued.

Thus, the article will travel in reverse. It will not begin with a sketch of the situation prior to World War II and then outline the situation that led to the creation of the UNHCR in the context of the conflict over Palestine, but rather end there. For with the creation of IRO and its successor, the UNHCR, new principles for resettling refugees were set forth to override (but not totally displace) the older principles of mass population exchanges and transfers. With the onset of the Cold War, the contrast emerged between refugees as products of war to a shift in emphasis to those who are the result of state oppression. This shift was quite compatible with the original goals and boundary conditions. The legal foundation of asylum and its ostensible relationship to human rights emerged as the UNHCR developed in parallel with the centrality of the Cold War. But with the end of the Cold War, the UNHCR put a major emphasis on repatriation, an emphasis which I believe even preceded the end of that war. The current emphasis, I argue, is that the refugee issue is viewed by the UNHCR through a security lens. Not simply state security. Rather, security is more broadly defined to include issues such as social security, economic security, and environmental security, all encompassed by the phrase "human security." This current emphasis is not a deviation, let alone a radical departure, from the emphasis on repatriation or the earlier one of legal protection or the even earlier stress on the aid/development continuum. It was built into the possibilities of the UNHCR from the beginning. That is the essence of the argument that I put forth.

\section{THE INTERNALLY DISPLACED}

A key part of the UNHCR position is summed up in the following clauses of a UNHCR Report (2000):

UNHCR has an interest in the protection and welfare of persons who have been displaced by persecution, situations of general violence, conflict or massive violations of human rights, because of their similarity to refugees in terms of the causes and consequences of their displacement and humanitarian needs. 
This interest, arising from the Office's humanitarian mandate and endorsed by successive General Assembly resolutions, places upon UNHCR a responsibility to:

- advocate on behalf of the internally displaced;

- mobilize support for them;

- strengthen its capacity to respond to their problems; and

- take the lead to protect and assist them in certain situations.

In view of the growing linkages between refugee problems and internal displacement, UNHCR is committed to greater engagement with the internally displaced within the parameters of its principles and prerequisites for operational involvement.

This wider focus beyond refugees and its connection with the concept of human security can be traced to an earlier UNHCR paper prepared by Jeff Crisp. In it, the following position was taken:

First, the notion of reintegration cannot be restricted to returning refugees. When a civil war or communal conflict comes to an end, many other groups of people (some of whom may not be of direct concern to UNHCR) are also confronted with the task of rebuilding their lives and communities: displaced and war-affected populations, demobilized soldiers, and the victims of ethnic cleansing, to give just a few examples. The reintegration process must not only address the situation of these different groups, but musc also promote peaceful and positive interactions between them, thereby contributing to the objective of social and political reconciliation. It is therefore essential that UNHCR's reintegration activities adopt a communitybased approach, rather than being specifically targeted at returning refugees.

Second, UNHCR's reintegration efforts must contribute to broader goals than the promotion of self-sufficiency. Of course, it is essential to ensure that formerly displaced people and other members of society can meet their material needs and enjoy a satisfactory standard of living. But it is equally important to ensure that they enjoy a progressively greater degree of physical, legal, social and psychological security. Only by addressing the issue of human security in this multi-dimensional manner, and by combining the efforts of UNHCR with those of other actors, is it possible to consolidate the reintegration process and to prevent continued instability. In this respect, particular attention should be given to the way in which UNHCR's reintegration activities can contribute to social and political reconciliation in societies which have experienced violence and armed conflict.

\section{THE UNHCR AND THE SECURITY PARADIGM}

Instead of discoursing at length on the character, justification and implications of the UNHCR operating within the relatively newly minted notion of human security, I set forth many of the key propositions of the security paradigm within which the UNHCR is now attempting to grasp its mandate. 


\section{Reconceptualizing Security}

1. There has been an intellectual shift in the definition of security once restricted to the study of the threat and use of military force with a concern with its control and management in an interstate context.

2. The conception of security has shifted to the much broader notion of "human security, encompassing non-military and non-state threats (see Krause and Williams, 1997; Baldwin, 1997; Buzan, Waever and de Wilde, 1998).

3. The traditional realist concerns with state security in the new context emphasizes the need to tighten border controls, prevent human smuggling, and stop asylum seekers who may simply be fleeing poverty or a war.

4. This emphasis is at odds with the liberal emphasis on humanitarianism and human rights and, hence, refugee protection encompassed by the larger human security doctrine (see Lavenex, 2000).

5. Human security is expected to encompass both the old notions of state security and the new non-state threats, thereby embracing the notions of protection and human rights; however, by defining refugees as one key source of threat to state security, the notion of "human security" disguises rather than resolves the contradiction (see Hammerstad, 2000) and increases insecurity for the displaced and refugees in places such as Africa.

\section{The Prime Threats to Security}

6. As the threat of nuclear confrontation has receded, the tolerance for intra-state wars has increased.

7. As totalitarian regimes on the left demonstrated that the ideology on which they were founded was inherently flawed, ethnic conflicts have moved out from the shadows of repression to occupy one ring of the current three ring circus.

8. As the authoritarian, military regimes on the right proved that they were unable to bring about long-lasting economic prosperity but rather economically corrupt regimes, largescale criminosis emerged as a primary security threat to occupy a second circus ring in our present volatile world; this criminality ranges from car hijackings and seizure of natural resources, such as diamond mines, by militarized forces to what is considered by many American officials to be the most dangerous and threatening issue - narco-traffickers.

9. Though the realms of interethnic conflict and criminal operations interpenetrate one another, they are, in fact, viewed as separate and discrete phenomena. 
10. Refugees are no longer viewed primarily as indicators of the oppression of the other (and, hence, labeled as "freedom fighters") and of our own tolerance and humanitarianism, but are increasingly viewed as threats to our own stability, particularly as the new information economy has a declining need for raw labor.

\section{Responses to those Threats}

11. The movement of large populations displaced by violent conflict or induced to move by human smuggling rings are generally dealt with separately.

12. Populations forced to move are not only the by-products of such conflicts, but strategic outcomes and even one ultimate intention of violent conflict.

13. The lion tamer, whether it is taken as the Security Council or as the United States (the remaining global superpower) not only locates the lions and the tigers in opposite circus rings, allowing them free reign outside of their cages, but himself occupies a separate ring in the center.

14. The lion tamer is unwilling to enter a ring with either tigers or lions let alone one in which they are in the same cage; he cracks his whip, but is unwilling to risk human resources to tame these wild beasts.

15. Though Western strategies have shifted to emphasize the mitigation and prevention of violent conflict and of international criminality with respect to forced population moves, there is no coherent strategy or parallel resolve to commit the human and material resources to even attempt to accomplish the task.

\section{Changes to the UNHCR}

16. In response to these challenges, the UNHCR during the nineties emerged as the preeminent humanitarian agency in the midst of these complex emergencies.

17. The UNHCR traditional concern with refugee protection has become intimately intertwined with the new role of peacekeepers in intra-state conflicts.

18. As a result, the security of its own humanitarian workers is now a preeminent concern (see UNHCR, 1998).

19. Temporary protection rather than permanent resettlement in third countries of resettlement has been emphasized.

20. Repatriation, even from countries of first asylum, has been given enhanced 
- some argue exclusive - emphasis, including the willingness to tolerate induced or even forced repatriation efforts (see Black and Koser, 1999).

\section{Refugees as Security Threats}

21. Further, those same refugees have been used and recruited as refugee warriors (UNHCR, 1999), and the humanitarian aid directed at refugee relief has been utilized to fund the acquisition of arms (Crisp, 1999).

22. Support from a refugee receiving state has often been used to enable refugees to mobilize militarily, causing conflict to spread across borders (see, e.g., Lischer, n.d.).

23. As a result, that insecurity has been extended to humanitarian workers in the field as psychopathic war criminals, often using child soldiers and/or refugees, have targeted relief personnel (Weiss, 1999).

24. The result has been that humanitarianism can no longer be separated from politics; to protect organizational mandates, humanitarians have to be very sensitive to the political context in which they operate.

25. This political sensitivity means that the vaulted principles of neutrality, avoiding taking sides with either of the parties in dispute, and impartiality, the positive obligation to treat each side with evenhandedness in dealing with refugees, have had to be set aside in contexts where this general insecurity prevails.

\section{IMAGINED POSSIBLE ROLES FOR THE UNHCR}

What other roles could UNHCR play? I do not mean to deal with actual possibilities, such as a return to roles that UNHCR has emphasized in the past. Rather, I am concerned with imaginative possibilities, with counterfactuals, to serve as foils for the present mode of defining its role.

I therefore begin by eliminating any reference to actual past roles that the UNHCR has played within the mandate of legal protector which, in certain periods, became the primary emphasis of UNHCR:

- political resettlement and integration of individuals fleeing communism

- material aid and diplomatic assistance (good offices) in the context of mass movements, initially largely from communist states, to enable both resettlement and sometimes reintegration

- humanitarian co-ordinator of humanitarian aid for settlement in countries of first asylum

- humanitarian aid agency for large scale resettlement in third countries (e.g., the Indochinese refugees) 
- humanitarian aid agency emphasizing repatriation

- an agency focused on all forced migration where it is appropriate and practical to act within the context of a human security framework

Do these not cover the gamut of possible activities? What else could UNHCR have taken on without assuming the role of a world government or a global humanitarian banker? Obviously there are possibilities beyond its mandate of providing legal protection for refugees. These possibilities focus both on helping refugees and on its legal mandate. They are intended to be suggestive rather than exhaustive.

I now describe one actual historical possibility that once was assumed by international agencies within the context of state and national security and not with the emphasis on the protection of the refugees themselves. In order to establish state security, the exchange of populations and the forcible removal of peoples was internationally sanctioned. When the century began, refugees were viewed as products of war largely between states rather than primarily as products of state oppression. The Greek-Turkish conflict following World War I is an example. In that conflict, population exchanges (now known as "ethnic cleansing") were not just permitted but were endorsed by the international order. Population exchanges were then given a positive moral value. For Greece (Hellas) was assumed to have a universal significance.

Greece epitomized universal values and the distinctive character of Europe as possessing a superior civilization (Canefe, 1998). In contrast, the disintegrating Ottoman empire stood for Oriental despotism and decadence. The struggle from the beginnings of the Greek Liberation movement one hundred years earlier from its state as an Oriental vassal (1821-29) to the reunion of all Greeks within that romantic vision of freedom and liberty a century later placed the separation of peoples within a moral context.

Though the Greeks had suffered many humiliations in that struggle (1854, 1897, 1908), beginning with the Balkan wars of 1912-13, the acquisition of territory and populations far exceeded anyone's expectations. However, that expansion had its limits. In the Anatolian adventure, rooted in Great Britain's Sir Edward Grey's offer in January 1915 to Greece of 'large concessions on the coast of Asia Minor' in return for Greece joining the Entente, Greece occupied Smyrna in May of 1919. The fact that Greeks only constituted about 20 percent of the population of Smyrna and Ionia ( 2 of 10 million) was ignored in the dream of a higher moral purpose. Sanctioned by the Allied Powers, the Greeks landed in Asia Minor to "protect local Greek and Armenian populations against a massacre." In fact, because of that ill- 
fated adventurism, the scattered Greek population that had lived in Anatolia for millenia was forced to relocate.

When the Kemalist forces attacked the Greeks in August 1922, the whole Christian population of Western Asia Minor followed the flight of the defeated Greek army to the Aegean islands and Thrace (the recently restored monarch was overthrown to purge Greece for such a humiliating defeat). In reaction to the homogenizing policies of the young Turks, tens of thousands of Muslim migrants from the Balkans and the Caucasus relocated to Turkey. In the fight for "Turkish independence," Anatolia and parts of eastern Thrace were redefined as the 'sole homeland of the Turkish people' (Landau, 1981, 1995). In the aftermath of the disintegration of the Ottoman empire, Turkey emerged as a Western, albeit an anti-imperialist, state. The cosmopolitan, multiethnic, multireligious heritage of the Byzantine empire and Muslim civilization were rejected along with the Ottoman and Islamic modes of governance.

But the struggle was also one for a new political morality. Each nation would have its own state to provide protection for the members of that state. The security of the individual was primarily the responsibility of the state insofar as that individual was a member of the nation which the state was dedicated to serve. The modern nation-state was given the sovereign power to exercise supreme authority over its territory and its citizens. The twentieth century can be viewed as an effort at building strong territorial nation-states as the common basis for modernization. In the process, subjects became citizens.

Unfortunately, most of the states created consisted of mixed populations. Turkey after World War I and Israel after World War II were created as ostensibly dominant national populations based upon the flight and even expulsion of long-settled historical communities. In both states, as in many with mixed populations, the modernization and secularization impulse produced a reaction by religious-based movements. But this gets us ahead of our story. The first quarter of the century was led by the dream of a free and unique people in a 'national homeland' governed by self-determination in which patria or loyalty was owed to one's people and the state as the protector of the heritage and destiny of that people.

The characterization of the Nazis as nationalists before and during World War II cast a sinister shadow on nationalism and particularly on the forced evacuation of populations. Though the ethos of the exchange of populations persisted after the war, the new ethos stressed protection of people rather than their forced movement. UNHCR was given a legal mandate to protect refugees and not a mandate to create refugees or solve problems of ethnic con- 
flict. There was no possibility of the UNHCR playing a role in facilitating the exchange of populations that occurred in Bosnia. Instead, the UNHCR tried to facilitate minority returns - that is, the return of refugees to areas where they would likely remain a minority even if they were once the majority. The fact that after the expenditure of enormous amounts of resources, the effort has been largely a failure should not be blamed on the UNHCR. The possibility of UNHCR acting to facilitate property exchanges and resettlement in majority areas was not part of the repertoire in the nineties.

A very different example of a possible activity, which I believe no international refugee organization has ever played, follows. As an organization with a legal mandate to protect refugees, it is possible to conceive of the UNHCR becoming a standard bearer for the "right of return." On the basis of the premise that once all territories were effectively governed by states, then every individual held a membership in a state to which he or she was entitled to membership, to return and to protection by that state. When states failed in that responsibility, the UNHCR could have taken the state or its rulers, using the threat to seize assets or deny travel rights as a form of pressure to ensure that the state acted to protect its citizens and did not produce refugees.

I am not suggesting that such a role was historically possible. I am suggesting it was conceptually possible. Further, there were historical actions that could have sanctioned such an activity. By March 23, 1976, the right of return, implied in the Universal Declaration of Human Rights, was articulated in the Uppsala Declaration (June 21, 1972), the Declaration on the Right to Leave and Return, Articles 9 and 10. "Every person is entitled to return to the country of which he is a national. No person shall be deprived of his nationality for the purpose of divesting him of the right of return to his country." Theoretically and based on international law, the UNHCR could have made the right to return its standard bearer.

There are obvious reasons why this was not a real possibility. For one, those fleeing communism did not want the right to teturn. Further, Palestinians had also been given a right to return, but that had a different meaning and a different origin (see Adelman, 1994). It was a right to return to homes and not a homeland. The Arabic word watana means to teside and sojourn in a place as well as to choose a place to live. Though it is now translated as an equivalent of patria, it is really associated with nostalgia and sentimental attachment to a particular place considered as home versus a sense of loyalty to a state and a national identity. When Count Folk Bernadotte added the right to return to the Rhodes documents, it was because he held 
the feudal belief that individuals had a natural affinity for the place to which they naturally belonged. It was a right to return to a particular place and not a state in which one held membership. It was a recipe unacceptable not only to the Israelis but to many others who would view it as a source of instability and further conflict rather than a mode of resolving the plight of refugees.

UNHCR became focused on repatriation when feasible and safe, rather than on asserting the rights of the refugees. In the interim, refugees were kept in camps or resettled in countries that would take them. My argument will be that it was not only political difficulties that stood in the way of UNHCR assuming the role of the champion of the right to return. UNHCR had never been programmed to assume that role as one of its possibilities.

There are probably a number of other examples of possible roles we could conceive for the UNHCR. I present just one other example in addition to facilitating population exchanges or becoming the legal standard bearer for the right to return. Refugees are very often the by-product and sometimes the intended result of the political machinations of political leaders wielding power without regard to the rights of its citizens or the responsibilities that politicians owe them. Recently, with the rise of the human rights movement led by Amnesty International since the seventies and joined by organizations such as Africa Watch, and in general with the mushrooming of the international lawyering movement in many other areas such as human health and the environment, domestic courts have been used to pursue justice. Instead of emphasizing root causes, the effort has been put into doing something about impunity. This has led to the creation of international courts to try the perpetrators of ethnic cleansing in Bosnia and of genocide in Rwanda. Most recently, this international effort led to the attempt to have Augusto Pinochet extradicted from Britain to be tried in Spain for crimes against humanity.

It is logically possible (to repeat, I am not dealing with empirical or historical possibilities) to conceive of the UNHCR using its legal mandate to protect refugees by ending the impunity of those who are ultimately responsible for the production of those refugees. It is imaginatively possible to conceive of the legal mandate given to UNHCR being used to pursue remedies in the courts on behalf of refugees against those who could be held responsible for their current status. As far as I know, it has never been tried. But given the precedents in other fields, it is a possibility. I argue that it is a possibility that was never explored because it was not one of the possibilities programmed into UNHCR when it was created. 


\section{THE PROGRAMMING OF THE UNHCR}

Programming does not start after we are born but in the circumstances which give rise to that birth and the conditions present when the infant organization is still in the womb. Further, when it born, the organization may have a different identity and metamorphose into what became the UNHCR. Let us back up a bit, not to the mass population exchanges endorsed by the international community before and even immediately after WWII.

The central issue of refugees concerns people who do not have membership in a state that ensures their protection. What is to be done with those who did not belong to any state? In the twenties, those who wanted to leave, or rather those that states wanted to encourage them to leave, could be given a Nansen passport so they could seek resettlement in countries that looked for new citizens and dreamed of forging totally new nations out of a polyglot of relocated individuals.

This was suitable for individuals, particularly when states were looking for migrants in the 1920s. But what happened when masses of refugees were fleeing who had no home state at a time when migrants were unwelcome? In the 1930s, under the pressure of the Depression and the rise of xenophobia, immigration countries closed their doors. In the context of the thirties, a new solution emerged to the problem of refugees. Instead of population transfers to create ethnically homogeneous populations, refugees were to be dealt with as individuals, to be repatriated if possible, and to be resettled under very restricted conditions if repatriation was not possible. This solution was not a product of human rights ideals with the onset of the Cold War. The principles emerged even before the onset of that half century of frozen belligerence. They were a by-product of a very different dialectic between the West and the East, this time between the Jews and the Orient rather than between Hellas and the Orient.

Two competing nationalisms were in conflict in the Middle East. That conflict was caught up in international power politics. The central issue was the right of Jews to immigrate to Palestine, a right that became a desperate need with the rise of the Nazis and then the horrific plight of the remnant of Jewish refugees after World War II.

Palestine at the time was not a separate state with sovereign control over who could enter as members. Palestine came into existence as a political entity separate from the Turkish Empire, as a territory placed under the political jurisdiction of the United Kingdom. The League of Nations had assigned the mandate over Palestine to Britain. The League of Nations confirmed the promise of the British Balfour Declaration for "the establishment in Palestine of a Nation- 
al Home for the Jewish people." That promise was qualified: "Nothing shall be done which may prejudice the civic and religious rights [note: not political rights] of the existing non-Jewish communities, or the rights and political status enjoyed by Jews in any other country." The indigenous population was not given the basic right of members of a state, the right to determine who and how many others could become members of its community.

Quite aside from various legal bases for their claims, the Arabs had a political claim based on a fundamental imperative. The issue was not simply two nationalisms in conflict, but two principles as well. One principle was that each nation in the world had the right to self-expression in a specific territory and the protection of a state to guarantee and secure the collective wellbeing of that nationality. The second principle was the right of an indigenous population to self-determination in the territory in which it lived. The primary principle on which the League of Nations was founded was the right of nations to self-expression in a territory. Self-determination, though an important principle for the League of Nations, was subsidiary to the principle of national self-expression. Further, both were subject to the reality of state power. The League of Nations was not set up to destroy or challenge the power of existing states on the principles of extranational self-expression or self-determination. These principles were only applicable in areas where a vacuum in state authority had been created as a result of the dissolution of empires following World War I.

The Arabs in Palestine had risen in violent protest in the 1920s to defend their convictions. They fought Britain in a full-scale revolt in 1937 after Jewish immigration from Europe in the early 1930s had increased the Jewish percentage of the population to over one third and just when the politics of immigration shifted to the issue of refugees. Jews were not simply suffering in Europe from a heritage of persecution which periodically manifested itself in pogroms. Hitler had come to power in Germany in 1933. By 1937, it was clear that the anti-semitism of the Nazis was now dictating government policy. Jews, who had suffered government-instigated discrimination, were now being persecuted. Jews in flight from persecution were becoming refugees in desperate need of a safe haven.

The Arabs, driven by their opposition to Jewish nationalism, opposed the use of Palestine as a sanctuary for Jewish refugees. In fact, the riots of 1936, which became a full-scale revolt in 1937, were in part motivated by the fear that the plight of the Jewish refugees in Europe and the reluctance of other countries to take in those refugees would inevitably result in the Jewish minority becoming a majority. 
Britain set up the Peel Commission in 1936 to examine the conflict between Arabs and Jews in Palestine and the political future of Palestine. Was the Jewish homeland to develop as an independent state, a part of a federal state, or within a binational territorial state? Was the Arab nation, which still constituted the majority, to be given control over the territory given their absolute denial of any national rights whatsoever to the Jews? In the Report of July of 1937, the Peel Commission attributed the underlying cause of the Arab revolt to the desire of the Arabs for national independence and their hatred and fear of the establishment of a National Jewish Home. They recommended freezing immigration at 12,000 per year for five years. The Peel Commission also recommended partition. For the Arabs, resolving the conflict by partition was anathema. They escalated the rebellion and claimed that the Mandate was invalid.

The Peel Commission, however, went further. It advised that "the most strenuous effort should be made to obtain an agreement for the exchange of land and population." This echoed Churchill's early characterization that the implementation of Zionism presumed a policy of population transfer. As the Peel Report stated, in the last resort, "the exchange would be made compulsory." The precedent cited was the Convention of Lausanne (1923), which provided, on paper, international legal sanction for the compulsory exchange of populations between Greece and Turkey.

The Peel Commission was not the first or only body to consider an exchange of populations as part of the solution to the Palestine dilemma. Chaim Weizmann and the British Colonial Secretary discussed an exchange of populations. Weizmann, in reply to a question from the Royal Commission on January 12,1937, implied that the country would not be able to assimilate the 400,000 Jews already present. Ben Gurion, after tremendous agonizing over the issue, concluded, "We must uproot from our hearts the assumption that the thing is not possible. It $c a n$ be done ... we must prepare ourselves to carry out the transfer provision (Ben Gurion, July 12, 1937; 2BG, vol. IV, p. 299, quoted in Ben Gurion and the Palestinian Arabs, New York, 1980:182)." The Labour Party Executive of Britain in 1944 recommended that "the Arabs be encouraged to move out as the Jews move in (National Executive Committee of the Labour Party, 1944). Ex-President Hoover conceived an even more grandiose scheme in 1945 - sending Palestinian Arabs to Iraq for resettlement on a huge irrigation scheme. In February of 1947, when Roosevelt met Weizmann for the first time, he "tried out his idea about moving the Arabs out" (Grose, 1983:138-139). Roosevelt 
independently came to the same conclusion as Hoover: "An ambitious plan was taking shape in his mind, a plan calling for the transfer of the entire Arab population of Palestine to a weaker Arab land" (Grose, 1983). American dollars with a dollop of British pounds and French francs would pay the development and resettlement costs.

As already stated, the ideology of internationally sanctioned population exchanges was the prevailing solution to refugees between World War I and even after World War II. For Jews, population transfer was not just a hypothetical possibility, but a reality. The Jews of Germany were being forced out of Germany, and there was nowhere for them to go. The Jews in the rest of Europe were threatened in a rising tide of anti-semitism. The problem was no longer the right to immigration and the realization of a national rebirth. The problem became the plight of Jewish refugees. The problem would become the very survival of the Jewish people. The Jews were desperate. The British denied the Jews a haven from Nazi atrocities they so desperately needed at the time, though Britain did not endorse the principle of self-determination of the majority.

In 1938, the Evian Conference was ostensibly called by Roosevelt to deal with the Jews of Germany who were attempting to flee but could not find countries that would receive them. In a public relations exercise, the rhetoric at the end of the conference stated that states had an obligation to those who lacked membership in a state that would provide protection. States accepted an obligation, unfortunately only in words, to provide a haven for refugees. But those meaningless words would be translated into meaningful principles after the war.

Those concerned with virtue might hope that the World War that followed, and the death of 6 million Jews through the Holocaust, would make a difference to both the Arab and the British positions. Only 100,000 debilitated skeletons of European Jews were left in the camps at war's end. The determination of the Arabs, and their ally, Britain, was revealed in their combined fight to resist transferring the international responsibility for the remnants of European Jewry to Palestine. To the roughly 100,000 Jews left in the Nazi concentration camps at war's end would soon be added another 100,000-150,000 Jews fleeing different parts of Eastern Europe that were under or about to come under Soviet control. What was to be done with these refugees? For the Jewish refugees with Zionist convinctions, who believed Zion was the only place where they would be both safe and fulfilled, Palestine was the obvious destination. Practically speaking, Palestine was also the only option as well for most Jewish refugees who were not ardent Zionists, 
given the reluctance of Western countries, even after World War II, to resettle Jews. The only other option was repatriation to the countries from which the Jews had fled, an unacceptable option for the Jews.

The Arabs, now assisted by the British, fought the pressure for entry of Jewish refugees from Europe into Palestine by two means in the international diplomatic arena. They fostered the idea of repatriation of the Jews and they tried to prevent Jewish resettlement in Palestine. The battle took place in the discussions in the Economic and Social Council (ECOSOC) over the draft constitution of the International Refugee Organization (IRO).

The Arabs fought to make the objective of the IRO, in dealing with the Jews, repatriation and not resettlement. To prevent resettlement in Palestine, they tried to introduce conditions to resettlement, namely the consent of neighboring countries and of the indigenous population. They also wanted the IRO to have exclusive authority to settle European refugees, largely through repatriation. They suggested that all private organizations working for resettlement transfer their assets to the IRO for that purpose.

In the IRO constitution, a distinction was made between refugees - pre or post- war victims of Nazi or fascist regimes or of racial, religious or political persecution - and displaced persons (DPs) who were displaced in the course of or after World War II. As far as the DPs were concerned, the IRO was "to encourage and assist in every possible way the early return to their countries of origin" (Annex 1, para. 1(b), Draft Constitution of the IRO, A/127). If Jews were classified as DPs, that classification would direct the IRO to arrange for their repatriation.

If Jews were classified as refugees, then Palestine was the obvious place for them to be resettled, given the terms of the Mandate and the limitation of other options. As the earlier Report of the High Commissioner for Refugees submitted to the Twenty-First Ordinary Session of the League of Nations Assembly had noted, "Palestine alone has made a contribution of any size" in reference to large-scale or group settlement of Jews.

The Arab countries, led by Egypt, attempted to set repatriation as the goal of the IRO for all persons, whether refugees or DPs. Mr. Kamel, the delegate of Egypt, proposed amending paragraph 2 of the Preamble of the Draft Constitution of IRO to require serious reasons to justify resettlement. Though defeated, on November 19, 1946, Kamel tried again unsuccessfully by proposing the deletion of the phrase "concerning displaced persons" from Annex I section IB. Passing the amendment would have meant repatriation was advisable for both refugees and displaced persons (Robinson, p. 15). 
These attempts to dry up the source of Jewish immigration to Palestine were not restricted to the Arab countries. The United Kingdom played a leading role. The British delegate, supported by the Lebanese delegate, opposed the provision (Annex 1, Part 1, Section H, para. 3) (which passed) defining German and Austrian residents of Jewish origin as 'refugees.' The opposition argued on what could be said to be very high moral principle the ostensible high ground that this was merely a backhanded attempt to clear Europe of its Jews - in other words to accomplish Hitler's goal of making the German-speaking parts of Europe "Judenrein" (A/C.3/61; A/C.3/68:5, 9). Though the British acknowledged the difficulty Jews would have in living in places where they had been so persecuted, they admitted their real motives when they declared their "fear that the new provision might well involve the new IRO in schemes for Jewish immigration into Palestine, a matter which is being separately dealt with by bodies specially concerned with that problem" (E/REF/87, May 30, 1946).

The main Arab effort, however, was not focused on repatriation but on the attempts to prevent resettlement of Jews in Palestine by placing specific conditions on resettlement. Dr. Malik of Lebanon attempted to qualify where the IRO could resettle refugees. He proposed that refugees could not be resettled where they "will create political difficulties in the countries of resettlement or in neighboring countries" or "without the consent of the peoples of the countries of reception and without full consultation with the States members of the United Nations most directly concerned" (E/86:6). These and many other efforts were defeated.

It was clear that all these legal maneuvers were aimed specifically at stopping Jewish migration to Palestine. An attempt was made to give the IRO exclusive jurisdiction over the DPs and refugees by transferring the assets of the Jewish Agency and the JOINT (the American Jewish Joint Distribution Committee) to the IRO. All these proposals failed. The clearest indication of support for the Jewish refugees going to Palestine emerged in the Committee on Finances of the IRO which, in its 1947 budget, provided for the use of German reparation funds to resettle 100,000 Jewish refugees, with the funds to be transferred to the JOINT and the Jewish Agency.

The Arabs, backed by the British, were defeated in the attempt to make repatriation the exclusive function of the IRO or to include Jews in those slated for repatriation. Even when repatriation was argued on the highest morals grounds of equality, nondiscrimination and the opposition to a Europe free of Jews, the Arabs and British were unable to succeed in target- 
ing the Jews for repatriation. When the major efforts focused on resettlement, they were unable to hedge the resettlement plans with conditions that would exclude Palestine as a target area for resettlement of the remnants of European Jews. The Jews, who had no votes in the UN, won every single moral and legal battle in the issue of resettling Jews in Palestine.

But this had no effect on actually allowing the Jewish entry into Palestine. Britain was in charge of Palestine. Britain controlled the gates of entry. Whatever sympathy existed for the Jews, Britain stubbornly clung to its commitments of the White Paper restricting Jewish entry into Palestine. Power, not law, and certainly not moral principles, seemed to be the determinant of the fate of the remnant of European Jewry. Further, though the series of decisions on repatriation and resettlement were clear and unequivocal, the Arabs and their British ally continued to interpret the IRO constitution in such a way as to restrict the access of the Jews to Palestine.

Out of the impasse of power and principle, out of the conflict of competing viewpoints, emerged the principles that governed the IRO and which set the foundation for the UNHCR. The following guiding principles emerged from the discussion of the refugee problem as a whole and from the decisions adopted by the United Nations with respect to the IRO.

1. Genuine refugees and displaced persons constitute a problem which is international in scope and character (see first paragraph of preamble to the Constitution of the IRO).

2. Refugees and displaced persons should return to their countries of origin (see second and third paragraphs of preamble and article 2, paragraph Ia).

3. Only in cases where refugees cannot be repatriated should steps be taken to resettle them elsewhere than in their countries of origin (see article 2, paragraph Ib).

4. In the performance of its functions, the IRO should act in accordance with the purposes and the principles of the United Nations, in particular as regards the resettlement of refugees and displaced persons in countries able and willing to receive them (see article 2, paragraph I).

5. In addition, the IRO should carry out the functions set forth in its Constitution in such a way as to avoid disturbing friendly relations between nations (see Annex I to the Constitution, paragraph Ig).

6. The IRO should exercise special care in resettling refugees or displaced persons either in countries contiguous to their respective countries of origin, or in non-self-governing territories and should also give due weight to any evidence of genuine apprehension and concern felt in regard to such plans, 
in the former case by the country of origin of the persons involved, in the latter case by the indigenous population of the non-self-governing territory in question (see Annex I, paragraph Ig).

Note the following distinctions:

1. Genuine refugees versus displaced persons as products of war;

2. Priority given to repatriation;

3. Resettlement was to be targeted at countries able and willing to receive refugees;

4. In such activities, nothing should be done to upset friendly states.

A new foundation had been laid very different than the previous practice of population transfers and exchanges. Yet as far as the Jews (or the Arabs) were concerned, population exchanges and transfers were the order of the day. In fact, that was the original intent of the United Nations Relief and Rehabilitation Agency for Palestine Refugees (UNRWA). The goal was to foster economic development in order to resettle the displaced Palestinian population and, thus, effect a population transfer. UNRWA was created to carry forth a new version of population transfer based on economic incentives rather than coerced movements. It had continued to exist for almost the same period as UNHCR, as a shadow reminder of a different ideology for dealing with refugees.

As far as Britain and the Arabs were concerned, the wishes of the refugees themselves counted for nothing. The rulings of international bodies counted for little more. Law and moral claims seemed to be mere backdrops. When the law and moral issues conflicted with political, military and material interests, a rhetoric of higher moral principles might be used - equality, universality - but the law was construed to support the positions already adopted. Further, there would be no recourse to morality or law to resolve the dispute, particularly when the series of rulings on the IRO constitutional disputes about refugees had been so clear.

In other words, just as the Nansen passports served to enable states to get rid of people whom they did not want, so the charter of the IRO enabled Europe to solve its postwar refugee problem. By distinguishing between DPs slated for repatriation and refugees slated for resettlement in contiguous countries - countries willing to receive them and non-self-governing states a match was made between different types of refugees, different solutions and matching opportunities to effect those solutions. And it was all done within the confines of the power politics of the time. 
However, in the process the template of IRO and thus of the UNHCR was set. Refugees had to be distinguished based upon persecution from others forced to migrate for other reasons. For those others, repatriation was the preferred solution. Internationally sanctioned population exchanges were not endorsed. Refugees suffering persecution would not be forced to return. On the other hand, their resettlement would only be undertaken either in countries willing to receive them or in non-self-governing territories. All such policies were to be carried out in such a way that 'friendly' states would not get upset. Would anyone deny that these have not been the operating parameters of UNHCR?

\section{CONCLUSION}

This was the template on which the UNHCR was founded. UNHCR operates within the constraints of power politics. The repatriation, settlement or resettlement solutions are all restorative. UNHCR has never been vested with a true preventative mandate. Sometimes one, sometimes another restorative strategy is tried, depending on time and circumstances. The template would not have enabled the UNHCR to become a legal crusader either to punish those who could possibly be held responsible for producing refugees or to insist on rights to membership of the refugees, whether in their home states or any others in which they might settle. Given the past of internationally sanctioned population exchanges to which the UNHCR was ostensibly morally opposed, one could not imagine the UNHCR being vested with such a responsibility. In my view, the current effort to place the mandate of the UNHCR within a paradigm of human security is merely the effort to recognize the full range of its activities and encompass them within a coherent frame, one that acknowledges the realpolitic within which UNHCR operates. However, the possibility of UNHCR becoming a crusader for membership rights of refugees or for pursuing the victimizers of the refugees through the courts seems remote. So is the role of UNHCR facilitating population exchanges even when that solution may be the only realistic answer to the problem of the refugees under the circumstances.

\section{REFERENCES}

Adelman, $\mathrm{H}$.

1994 "Refugees: The Right of Return." In Group Rights. Ed. J. Baker. Toronto: University of Toronto Press. Pp. 164-185.

Baldwin, D.

1997 "The Concept of Security," Review of International Studies, 23:5-26. 
Black, R. and K. Koser, eds.

1999 The End of the Refugee Cycle? Refugee Repatriation and Reconstruction. Oxford: Berghahn Books.

Buzan, B., O. Waever and de Wilde

1998 Security: A New Framework for Analysis. Boulder: Lynne Rienner.

Canefe, $\mathrm{N}$.

1998 "Sovereign Utopias: Civilisation Boundaries of Greek and Turkish Nationhood (1821-1923)." Ph.D. dissertation. York University. March.

Chimni, B. S.

1998 "The Global Refugee Problem in the 21st Century and the Emerging Security Paradigm: A Disturbing Trend." In Legal Visions of the 21st Century. Ed. A. Anghie and Sturgess. The Hague: Kluwer Law International.

Crisp, J.

1999 "A State of Insecurity: The Political Economy of Violence in Refugee-Populated Areas of Kenya." Working Paper No. 16, "New Issues in Refugee Research."

Goodwin-Gill, G.

1999 "Refugee Identity and Protection's Fading Prospect. In Refugee Rights and Reality. Ed. F. Nicholson and P. Twomey. Cambridge: Cambridge University Press. Pp. 220-552.

Grose, P.

1983 Israel in the Mind of America. New York: Alfred A Knopf, 1983

Hammetstad, A.

2000 "Whose Security? UNHCR Refugee Protection and State Security after the Cold War." Unpublished paper presented at the International Studies Association, Los Angeles, March.

Krause, $K$. and $M$. Williams

1997 Critical Security Studies: Concepts and Cases. London: UCL Press.

Landau, $]$.

1981

1985 Pan-Turkism in Turkey: A Study of Irredentism. London: C. Hurst.

Lavenex, $S$.

2000 "Migration and the EU's New Eastern Border: Between Realism and Liberalism," Journal of European Public Policy.

LeDoux, J.

1999 "The Power of Emotions." In States of Mind: New Discoveries about How Our Brains Make Us Who We Are. Ed. R. Conlan. New York: John Wiley \& Sons.

Lischer, S. K.

n.d. "Militarized Refugee Populations: Humanitarian Challenges in the Former Yugoslavia." http://web.mit.edu/cis/www/migration/milit.htm

Loescher, G. and J. Scanlan

1986 Calculated Kindness: Refugees and America's Half-Open Door. New York: Free Press.

Miskel, J.

"Migrant Smuggling from the Security Perspective." Unpublished.

National Executive Committee of the Labor Party

1944 "International Post-War Settlement Report." Labor Party Conference Report. December. 
Ogata, S.

1999 Statement, UNHCR, to the Third Committee of the General Assembly of the United Nations, November 12.

1992 Statement, UNHCR, to the Third Committee of the General Assembly of the United Nations, November 10.

Roberts, A.

1998 "More Refugees, Less Asylum: A Regime in Transformation," Journal of Refugee Studies, 11(4):375-395.

Shabtai, T.

1985 Ben Gurion and the Palestine Arabs. From Peace to War. Oxford: Oxford University Press, 1985.

United Nations

1999 "Internally Displaced Persons." Report of the Special Representative of the SecretaryGeneral. E/CN.4/1999/79, January 25.

United Nations High Commissioner for Refugees (UNHCR)

1999 "The Security and Civilian and Humanitarian Character of Refugee Camps and Settlements." UNHCR EXCOM Report. January 14.

1998 "The Humanitarian Debate: Context and Contents," Refugee Survey Quarterly, 7:1.

Weiss, T. G.

1999 "Principles, Politics, and International Affairs," Ethics \& International Affairs, 13:1-22. 